\title{
A Combination of Soursop and Lemongrass Leaves Extract as a Vegetable Biopesticide
}

\author{
$1^{\text {st }}$ Cornelia.M.A. Wattimena ${ }^{1}, 2^{\text {nd }}$ Fransina.S. Latumahina ${ }^{2}, 3^{\text {rd }}$ Maya. M.S. Puttileihalat ${ }^{1}$ \\ fransina.latumahina@yahoo.com $\left.{ }^{2}\right\}$ \\ Forestry Study Program, Pattimura University Ambon Maluku, Ambon, Indonesia ${ }^{1,2,3}$
}

\begin{abstract}
This study aimed to determine the concentration comparison of the combination of soursop and lemongrass leaves extract that is most effective as a vegetable biopesticide against the death of leaf caterpillars (Plutella xylostella) in mustard plants (Brassica juncea (L) and leaf caterpillars (Spodoptera plusia hymenia) on spinach (Amaranthus sp). This research was an experimental study using a Completely Randomized Design (CRD) consisting of 1 factor, namely the concentration of a combination of soursop and lemongrass leaves extract with three treatments. Namely T1 (100 soursop leaves +100 grams of lemongrass leaves), T2 (75 soursop leaves +50 grams of lemongrass leaves, T3 (50 soursop leaves +150 -gram lemongrass leaves), which was repeated three times on mustard and spinach plants. If there were a significant difference, the treatment would be continued with a different test at the level of $95 \%$ and $99 \%$ The results showed the effect of combination of soursop and lemongrass leaves extract in $\mathrm{T} 1$ treatment was higher because of death of caterpillars (Plutella xylostella) as many as 25 tails then T3 with mortality of 14 leaf caterpillars and the lowest effect was T2 treatment with penalty of 13 tail caterpillars. In contrast, the end of leaf caterpillars (Spodoptera plusia hymenia) in the T1 treatment was 25 tails, which was higher than T2 and T3, which only 14 tails, respectively.
\end{abstract}

Keywords: Vegetable biopesticides, soursop leaves, lemongrass leaves, caterpillars

\section{Introduction}

Public demand for mustard and spinach needs is always increasing, while mustard and spinach production in Ambon City is still relatively low. One of the factors causing the small production is pest attack, especially leaf caterpillars (Plutella xylostella) on mustard plants and leaf caterpillars (Spodoptera plusia hymenia) on spinach plants. Pests and pathogens attack results in crop loss and reduce yield quality, so it needs to be controlled.[1] Farmers, especially in Ambon City, prefer to use chemical pesticides rather than using vegetable pesticides. This is because it is easier for farmers to get it, and once the eradication action takes place, the pest dies immediately. Farmer's dependence on chemical pesticides in crop cultivation has caused environmental pollution, the emergence of pest resistance, decreasing natural enemy populations. This impact can affect the sustainability of agricultural production. The use of synthetic chemical pesticides has 
caused various undesirable effects, including damage to agrarian land ecosystems due to flora and fauna Therefore, we need an environmentally friendly technology that can control intruding organisms such as vegetable pesticide technology. This technology transfer becomes essential to reduce or eliminate farmers' dependence on chemical pesticides. [2]

Now days, it has been developed with environmentally friendly biopesticides. The biopesticides are easily degraded by sunlight and are washed off the ground, do not cause biotypes or new breeds of pests and diseases, and do not cause resistance. [3] Biopesticide is a pesticide made from plants. Plants are rich in active ingredients that function as a natural defense tool against intruders. Biopesticides work as repellents, attractors, antifertility, killers, and other forms. The active ingredients of vegetable pesticides are natural products derived from plants that have secondary metabolite groups that contain thousands of bioactive compounds such as alkaloids, terpenoids, phenolics, and other secondary chemical substances. [4] When applied to plants that are infected with pests (plant-disturbing organisms), these bioactive compounds do not affect growth photosynthesis or other plant physiological aspects but change the nervous system of muscles, hormonal balance, reproduction, behavior in the form of attractors, anti-food and respiratory system of pests. [2]. Research Problem from this paper is How is the effect of the concentration comparison of soursop and lemongrass leaves that is most effective as a biopesticide on the death of leaf caterpillars (Plutella xylostella) in mustard plants (Brassica juncea (L) and leaf caterpillars (Spodoptera plusia hymenia) on spinach (Amaranthus spp.)

\section{Method}

The study was conducted at the Silviculture Laboratory of the Department of Forestry, Faculty of Agriculture, Pattimura University Ambon, in January 2019. The tools and materials needed were: glass jars, cotton, sprayer, soft cloth, blender, scales, camera, and stationery, while the materials used were: soursop leaves, lemongrass leaves, caterpillars (Plutella xylostella) on mustard plants (Brassica juncea (L) and leaf caterpillars (Spodoptera plusia hymenia) on spinach plants (Amaranthus spp.), cotton, 70\% alcohol, tissue, knife, and gauze.

\subsection{Preparation of Soursop and Lemongrass Leaves Extract}

The procedure of research on the extract of soursop and lemongrass leaves was as follows:

1. Take soursop and lemongrass leaves following the concentration of T1 (100 grams of soursop leaves +100 grams of lemongrass leaves), $\mathrm{T} 2$ ( 75 grams of soursop leaves +50 grams of lemongrass leaves), T3 (50 grams of soursop leaves +150 grams of lemongrass leaves) and then leaves were mashed.

2. After mashed, it was soaked in 10 liters of water for 24 hours.

3. Then, the immersion water that has been soaked for 24 hours was filtered using a soft cloth, so that the soursop and lemongrass leaves were obtained with various concentrations.

\subsection{Application of Soursop and Lemongrass Leaves}

Firstly, the researchers prepared the sterile glass jar first and then put in a sterile cotton swab at the bottom of the pot, then mustard leaves and spinach leaves. After that, the researchers took 
90 leaf caterpillars (Plutella xylostella) on mustard plants and also 90 leaf caterpillars (Spodoptera plusia hymenia) on Spinach plants (Amaranthus spp.). Then, leaf caterpillars (Plutella xylostella) on mustard plants and leaf caterpillars (Spodoptera plusia hymenia) on spinach plants were placed in jars, covered with gauze and then sprayed with soursop and lemongrass leaves extract with different concentration. The ten tails were needed for each treatment.

This study was an experimental study using a Completely Randomized Design (CRD) consisting of 1 factor, namely the combined concentration of soursop and lemongrass leaves extract with three treatments that were repeated three times. The treatments were T1 (100 grams of soursop leaves +100 grams of lemongrass leaves), T2 (75-gram soursop leaves +50 -gram lemongrass leaves), T3 (50-gram soursop leaves +150 -gram lemongrass leaves). The tabulated data were then analyzed using Variant Analysis. If there was an influence, it was carried out with a different test at the level of $5 \%$ and $1 \%$. The parameters observed were the death of caterpillars (Plutella xylostella) and leaf caterpillars (Spodoptera plusia hymenia) for 24 hours of observation carried out in the morning and evening. The success of this research was the death of leaf caterpillars (Plutella xylostella) and leaf caterpillars (Spodoptera plusia hymenia) due to the giving of soursop and lemongrass leaves extract with various concentrations.

\section{Results}

The concentration of soursop and lemongrass leaves extract gave different effects on the death of leaf caterpillar (Plutella xylostella) on mustard plants. It can be seen in Table 1.

Table 1. Death of Caterpillars (Plutella xylostella) with Various Concentrations of Combination Soursop and Lemongrass Leaves Extract in Mustard (Brassica juncea (L))

\begin{tabular}{ccccccc}
\hline \multirow{2}{*}{ Treatment } & \multicolumn{3}{c}{ Repetition } & \multirow{2}{*}{ Total } & \multirow{2}{*}{ Average } \\
\cline { 2 - 4 } & I & II & III & & 26 & 9 \\
T1 & 7 & 10 & 9 & 13 & 4 \\
T2 & 4 & 5 & 4 & 4 & 14 & 5 \\
T3 & 5 & 5 & 17 & 53 & 18 \\
\hline Total & 16 & 20 & 6 & 18 & 6 \\
\hline Average & 5 & 7 & & & \\
\hline
\end{tabular}

Note:

$\mathrm{T} 1=100$ grams of soursop leaves +100 gram betel leaf +10 liters of water

$\mathrm{T} 2=75$ grams of soursop leaves +50 gram citronella leaf +10 liters of water

$\mathrm{T} 3=50$ grams of soursop leaves +150 grams of lemongrass leaves +10 liters of water 
Table 2. The Test Results of Variants Analysis of the Death of Leaf Caterpillars (Plutella xylostella) on Mustard Plants (Brassica juncea (L).

\begin{tabular}{ccccccc}
\hline \multirow{2}{*}{ Sources of Variants } & \multirow{2}{*}{$\mathrm{Db}$} & \multirow{2}{*}{$\mathrm{JK}$} & $\mathrm{KT}$ & \multirow{2}{*}{ F Hit } & \multicolumn{2}{c}{ F Table } \\
\cline { 3 - 7 } & 2 & 34.889 & 17.444 & $17.444^{* *}$ & 5.14 & 10.92 \\
\hline Treatment & 6 & 6.000 & 1.000 & & & \\
Random & 9 & 40.889 & & & & \\
\hline Total & & &
\end{tabular}

$\mathrm{KK}=17.0 \%$

Note $: * *$ Very Significant Differences at Test Levels of $5 \%$ and $1 \%$

Table 3. The Results of Tukey's Test Treatment of Soursop and Lemongrass Leaves Extract Concentration on Death of Caterpillars (Plutella xylostella) on Mustard Plants (Brassica juncea (L).

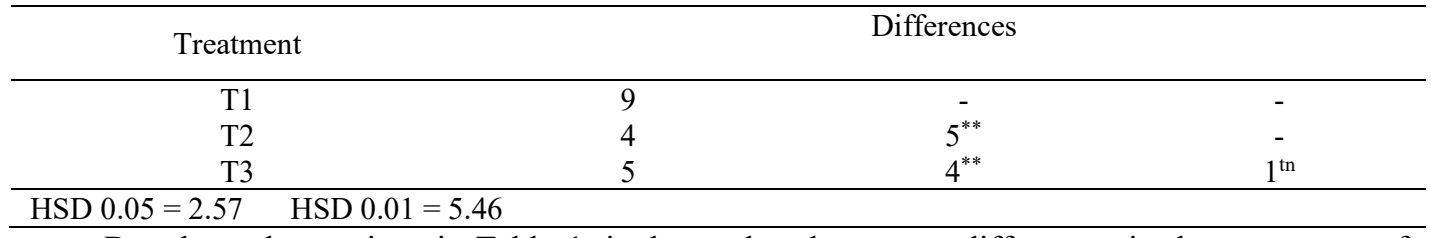

Based on observations in Table 1, it shows that there were differences in the treatments of T1, T2, and T3 with three replications and the total 30 leaf caterpillars (Plutella xylostella), which consisting of 10 leaf caterpillars (Plutella xylostella) in each treatment. The percentage of leaf caterpillar death in the treatment T1 was $86.67 \%$ with 26 died leaf caterpillars, the percentage of sheet caterpillar death in the treatment T2 was of $43.33 \%$ with 13 died leaf caterpillars, and the percentage of leaf caterpillar death in the treatment T3 was $46.67 \%$ with 14 died leaf caterpillars. This shows that every plant was always contained poison or the nature of organic compounds with different contents. According to [5] that each plant that contains toxins has different concentrations that the higher the level, the more amount of toxins on the skin of insects so that it can inhibit growth and cause more death of the insect. Soursop and lemongrass leaves also contain viruses. As in Table 1, all the treatments carried out lead to the end of caterpillars (Plutella xylostella). This shows that the higher the concentration, the higher the death of caterpillar leaves. It was possibly because of the higher the level of soursop and lemongrass leaves, the higher the toxin contained in the extract. Whereas in Table 3, the different values between treatments show that the treatment $\mathrm{T} 1$ to treatment $\mathrm{T} 2$ and treatment $\mathrm{T} 1$ to treatment $\mathrm{T} 3$ have a very significant effect. In contrast, treatment $\mathrm{T} 2$ to treatment $\mathrm{T} 3 \mathrm{did}$ not have a considerable impact. This explains that the higher the concentration of biopesticide given, the higher the toxin produced, but did not cause environmental damage because the active ingredients of vegetable pesticides quickly decomposed so that the residue was relatively not polluting the environment. Therefore, agricultural products were relatively safe for consumption even though shortly before harvest, the farmers still take pest control measures. However, because of its biodegradability, plant-based pesticides must be applied more intensively than synthetic pesticides to obtain optimal results. [6] The concentration of Soursop and Lemongrass Leaves Extract against Death of Leaf Caterpillar (Spodoptera plusia hymenia) on Spinach (Amaranthus spp). The concentration of soursop and 
lemongrass leaves extract gave different effects on the death of leaf caterpillar (Spodoptera plusia hymenia) on spinach plants. It can be seen in Table 4.

Table 4. The Death of leaf caterpllar (Spodoptera plusia hymenia) with Various Combination Concentrations of Soursop and Lemongrass Leaves Extract on Spinach (Amarathus spp)

\begin{tabular}{ccccccc}
\hline \multirow{2}{*}{ Treatment } & \multicolumn{3}{c}{ Repetition } & \multirow{2}{*}{ Total } & \multirow{2}{*}{ Average } \\
\cline { 2 - 5 } & I & II & III $n n$ & \\
T1 & 6 & 10 & 9 & & 25 & 8 \\
T2 & 5 & 5 & 4 & & 14 & 5 \\
T3 & 5 & 4 & 5 & 14 & 53 & 18 \\
\hline Total & 16 & 19 & 18 & 18 & 6 \\
\hline Average & 5 & 6 & 6 & &
\end{tabular}

Note:

$\mathrm{T} 1=100$ grams of soursop leaves +100 grams of lemongrass leaves +10 liters of water

$\mathrm{T} 2=75$ grams of soursop leaves +50 grams of lemongrass leaves +10 liters of water

$\mathrm{T} 3=50$ grams of soursop leaves +150 grams of lemongrass leaves +10 liters of water

Table 5. The Test Results of Variants Analysis of the Death of Leaf Caterpillar. (Spodoptera plusia hymenia) in Spinach Plants (Amaranthus spp)

\begin{tabular}{ccccccc}
\hline \multirow{2}{*}{ Sources of Variants } & \multirow{2}{*}{ Db } & \multirow{2}{*}{ JK } & KT & \multirow{2}{*}{ F Hit } & \multicolumn{2}{c}{ F Table } \\
\cline { 3 - 6 } & 2 & 26.889 & 13.444 & $8.067^{* *}$ & 5.14 & 10.92 \\
Treatment & 6 & 10.000 & 1.667 & & & \\
Random & 9 & 36.889 & & & & \\
\hline Total & & &
\end{tabular}

$\mathrm{KK}=28.3 \%$

Note : ** Very Significant Differences at Test Levels of 5\% and $1 \%$

Table 6. The Results of Tukey's Test on the Treatment of Soursop and Lemongrass Leaves Extract Concentration on Death of Caterpillars (Spodoptera plusia hymenia) on Spinach (Amarathus spp)

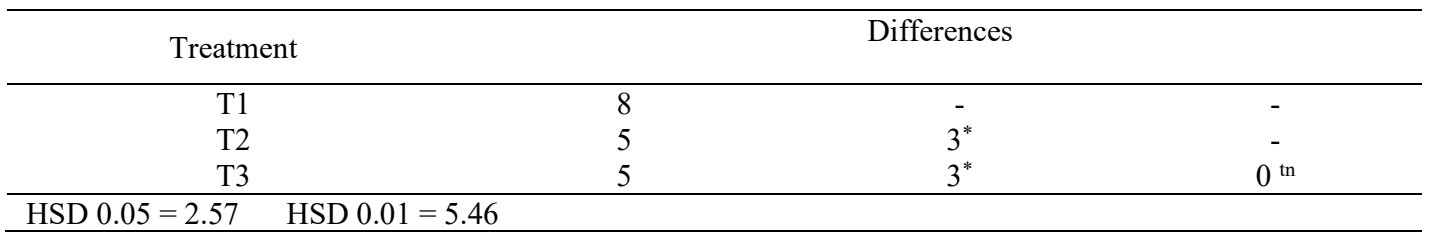

Based on observations in Table 4, it shows that there were differences in the treatments of $\mathrm{T} 1, \mathrm{~T} 2$, and T3 with three replications and the total 30 leaf caterpillars (Spodoptera plusia hymenia) which consisting of 10 leaf caterpillars (Spodoptera plusia hymenia) in each treatment. The percentage of leaf caterpillar death in the treatment T1 was $83.33 \%$ with 25 died leaf caterpillars, the percentage of sheet caterpillar death in the treatment T2 was of $46.67 \%$ with 14 died leaf caterpillars, and the percentage of leaf caterpillar death in the treatment T3 was $46.67 \%$ with 14 died leaf caterpillars. This shows that the higher the concentration, the higher the end of 
leaf caterpillars. It was possibly caused by the higher the concentration of soursop and lemongrass leaves that results in the more senior the toxin contained in the extract.

Furthermore, based on the different values between treatments, it was shown that the treatment $\mathrm{T} 1$ to treatment $\mathrm{T} 2$ and treatment $\mathrm{T} 1$ to treatment $\mathrm{T} 3 \mathrm{had}$ a real influence. In contrast, treatment of $\mathrm{T} 2$ against treatment $\mathrm{T} 3 \mathrm{did}$ not have a significant effect (Table 6).

\section{Discussion}

The results showed that giving a combination of soursop and lemongrass leaves extract with various concentrations did not cause direct death in leaf caterpillars (Plutella xylostella) and leaf caterpillars (Spodoptera plusia hymenia) but on endurance, nervous system and disruption of the respiratory system. According to [1] the concentration of toxic substances contained in the solution is following the amount of mass of the material used, if the level of content used is significant, the focus of poisonous substances contained in the answer will be high, and vice versa. This is also by the opinion of Sudarmo (2005) in Saifuddin (2016) who stated that plant-based pesticides could kill or disturb insect pests and diseases through unique ways of working, that is through a combination of various methods or singly and the more doses are given, the better the results obtained.[6]

The response is seen when spraying the extract on the leaf caterpillars (Plutella xylostella), and leaf caterpillars (Spodoptera plusia hymenia) were the two caterpillars that were trying to defend themselves from being contaminated by avoiding the extract in attempting to climb the walls of the container/jar provided. According to [5] contact poisons can be absorbed through the skin when administering insecticides or can also be exposed to residual pesticides (residues) sometime after spraying. It is similar to what is stated by [2] that there are also other compounds whose existence can increase overall extract activity (synergy) besides having the main active compounds in plant extracts. [7] About eating activities, insects can recognize foreign compounds in their food in specific concentrations and will respond to the presence of these compounds in their diet. The workings of stomach poison insecticides in the body of the insects is by entering the insect's digestive organs and is absorbed by the walls of the gastrointestinal tract. Furthermore, the pesticide is lowered by body fluids to a dangerous place. Therefore, firstly, insects eat plants that have been sprayed with insecticides. Tannins are compounds that can inhibit protein availability by forming complexes that are less digestible by insects.[8] Vegetable pesticides contain not only one type of active ingredient (single active ingredient), but several types of active ingredients (multiple active ingredients). Toxic power possessed by pesticide compounds is called toxicity. Factors that influence the poisonous nature of pesticides are 1) Toxicity of pesticide compounds. 2) Use of pesticide concentrations. 3) The duration of exposure to pesticides on plants under control. 4) The mechanism of pesticides entering the body of the plant.[2]

The combination of soursop and lemongrass leaves extract effect the death of leaf caterpillars (Plutella xylostella) and leaf caterpillars (Spodoptera plusia hymenia) because soursop (Annona muricata, L) leaves contain chemical compounds in the form of annanoin and resin. [9]This compound is known to be able to control leaf caterpillar pests and sucking pests (www.infoagribisnis.com) while on lemongrass leaves (Cymbopogon citratus) containing the main 
compounds that are essential oils. The essential oil of Lemongrass leaves consists of citral, citronella, geraniol, myrcene, nerol, farnesol Methil heptanol, and dependence compounds. [6] The most critical content is citronella, which is $35 \%$, and geraniol is $35-40 \%$. Citronella compounds have dehydrated poison properties; these poisons are contact poisons, which can result in death due to continuous fluid loss. Insects affected by this poison will die from a lack of fluids. Lemongrass leaves extract as a pest repellent. Thus, soursop and lemongrass leaves are plants that can be used as vegetable biopesticides. [10]

Vegetable biopesticides have advantages and disadvantages, as stated by [3]. The benefits include environmentally friendly, cheap, and easy to obtain, do not poison plants / agricultural products to be unhealthy, and do not cause immunity in pests. The disadvantages include; its working power is relatively slow, does not kill the target pests directly, unresistant to sunlight, and less practical because it must be sprayed repeatedly. Also, plant pesticides cannot be stored for a long time because their compounds are easily decomposed so that the longer they have saved, the weaker their toxicity. [11] Meanwhile, according to [12] the Utilization of vegetable pesticides has several advantages as well as weaknesses. One of them is that the active ingredients of vegetable pesticides quickly decompose so that the residue is relatively not polluting the environment, and agricultural products are relatively safe for consumption even though the farmers still take pest control measures just before harvest. However, due to its biodegradability, to obtain optimal results, plant-based pesticides must be applied more intensively than synthetic pesticides.[11]

\section{Conclusions}

The combination of soursop and lemongrass leaves, with various concentrations of treatment, gives a positive influence on the death of leaf caterpillars (Plutella xylostella) on mustard plants and leaf caterpillars (Spodoptera plusia hymenia) on spinach plants. The combination concentration of a soursop and lemongrass leaves extract in treatment T1 was higher in percentage on the death of leaf caterpillar (Plutella xylostella) in mustard plants, which was $83.33 \%$ (25 tails), when compared to treatments T2 and T3 namely: 46.67\% (14 tails) and 43.33\% (13 tails) respectively. The combination concentration of a soursop and lemongrass leaves extract on the death of leaf caterpillar (Spodoptera plusia hymenia) on spinach plants, for the treatment T1 was higher in percentage, namely: $83.33 \%$ (25 tails) while for the treatments T2 and T3 had the same death percentage; $46.67 \%$ (14 rears). To get maximum results on the death of caterpillars (Plutella xylostella) on mustard plants and leaf caterpillars (Spodoptera plusia hymenia) on spinach plants, it is necessary to do further research on the length of observation day.

\section{Referrences}

[1] P. Acharya, S. A. Mir, and B. Nayak, "Competence of Biopesticide and Neem in Agriculture," Int. J. Environ. Agric. Biotechnol., vol. 2, no. 6, pp. 2958-2964, 2017.

[2] G. E. Vallad, "Use of Biopesticides for the Management of Vegetable Diseases."

[3] S. Dayakar and Y. Subbarao, "Influence of addition of host larval extract to medium on the virulence of beauveria Bassiana (Balsamo) Vuillemin and Metarhizium anisopliae (metschnikoff) Sorokin against Spodoptera litura fab," J. Biopestic., vol. 4, no. 1, pp. 91-95, 2011. 
[4] N. Prakash, B. Kumari, and S. Karn, "Biopesticides: Introduction and its Prospects," Int. J. Curr. Microbiol. Appl. Sci., vol. 8, no. 02, pp. 2960-2964, 2019.

[5] S. Arivoli, S. Tennyson, and J. Jesudoss Martin, "Larvicidal efficacy of vernonia cinerea (1.) (asteraceae) leaf extracts against the filarial vector culex quinquefasciatus say (diptera: Culicidae)," J. Biopestic., vol. 4, no. 1, pp. 37-42, 2011.

[6] F. Guide, "How to Grow Crops without Endosulfan to Non-chemical Pest Management in," Network.

[7] M. IRFAN, “Uji Pestisida Nabati Terhadap Hama Dan Penyakit Tanaman,” J. Agroteknologi, vol. 6, no. 2, p. 39, 2016.

[8] F. Latumahina, M. Borovanska, Musyafa, Sumardi, N. S. Putra, and M. Janda, "Ants of Ambon Island - Diversity survey and checklist," Zookeys, vol. 472, pp. 43-57, 2015.

[9] T. E. Sari et al., "Pemanfaatan Daun Sirsak ( Annona muricata L .) pada Media Umpan sebagai Pengendali Rayap Tanah ( Coptotermes curvignathus Holmgren )," J. Protobiont, vol. 3, no. 1, pp. 71-74, 2014.

[10] W. Astuti and C. R. Widyastuti, "Pestisida Organik Ramah Lingkungan Pembasmi Hama Tanaman Sayur," Rekayasa, vol. 14, no. 2, pp. 115-120, 2016.

[11] S. Mazid, "A review on the use of biopesticides in insect pest management," Int. J. Sci. Adv. Technol., vol. 1, no. 7, pp. 169-178, 2011.

[12] "pada Tegakan Tusam ( Pinus merkusii Jung Et De Vriese ) Serai Wangi ( Andropogon nardus L .) as Original Insecticide on Pine Tree ( Pinus Jung Et De,” p. 100. 